\title{
Effect of Dunaliella salina on enhancing viability of probiotic and the nutritional value
}

\author{
Zina Alajil Alslibi ${ }^{1 *}$, Abuzer Çelekli² ${ }^{2}$ Hüseyin Bozkurt ${ }^{3}$ \\ ${ }^{1 *}$ Gaziantep University, Faculty of Art and Science, Departmant of 1Biochemistry Science and Technology, Gaziantep, Turkey, (ORCID: 0000-0001-9825-0910), \\ zozo12345.dd@gmail.com \\ ${ }^{2}$ Gaziantep University, Faculty of Art and Science, Departmant of Biology, Gaziantep, Turkey, (ORCID: 0000-0002-2448-4957), celekli.a@gmail.com \\ ${ }^{3}$ Gaziantep University, Faculty of Engineering, Departmant of Food Engineering, Gaziantep, Turkey, (ORCID: 0000-0003-4676-6354), hbozkurt@gantep.edu.tr
}

(1st International Conference on Applied Engineering and Natural Sciences ICAENS 2021, November 1-3, 2021)

(DOI: $10.31590 /$ ejosat.1013107)

ATIF/REFERENCE: Alslibi, Z. A., Çelekli, A. \& Bozkurt, H. (2021). Effect of Dunaliella salina on enhancing viability of probiotic and the nutritional value. European Journal of Science and Technology, (28), 1309-1311.

\begin{abstract}
Probiotics are known healthy exporters for humans utilized as diet supplements. Most types of probiotics like Lactobacillus applied in milk products possess various health benefits. Recently, fermented milk products contribute to the health of natural food and enhance intestinal microorganisms with the presence of lactic acid bacteria. As well as fermented milk products like kefir, ayran and yoghurt are supplement-power food is famous to be one of the most common of the best traditional fermented milk products in the world. Promoting the viability of probiotics like Lactobacillus acidophilus and Bifidobacterium with Dunaliella salina in fermented milk is an important issue. Nutrients consider as food components that could not be synthesized in our body such as vitamin $\mathrm{C}$ or could be synthesized that requires a specific factor in a certain state of affairs that be absent or not enough as some of the amino acids, vitamins and fatty acids as algae. The growing bodies of researches has applied on the biosynthetic ways of $\beta$-carotene in plants for perfection human health and nutrition and enhancing plant tolerance in hard environments. The effect of Dunaliella salina addition on the viability of probiotics bacteria in fermented milk through additions and storage time is a substantial issue. Thus, it is deemed as a "functional food". The aim of this study is to investigate the activity of probiotics and enhancing the nutritional value of fermented milk by adding Dunaliella salina.
\end{abstract}

Keywords: Dunaliella salina, Fermented milk, Probiotic bacteria, Algae, Functional food.

\section{Dunaliella salina'nın probiyotik canlılığını ve besin değerini artırmaya etkisi}

$\ddot{\text { Öz }}$

Probiyotikler, diyet takviyeleri olarak kullanılan insanlar için sağlıklı ihracatçılar olarak bilinir. Süt ürünlerinde uygulanan Lactobacillus gibi çoğu probiyotik türü, çeşitli sağlı yararlarına sahiptir. Son zamanlarda fermente süt ürünleri doğal gıdaların sağlığına katkı sağlamakta ve laktik asit bakterilerinin varlığı ile bağırsak mikroorganizmalarını geliştirmektedir. Kefir, ayran ve yoğurt gibi fermente süt ürünlerinin takviye edici gıda olmasının yanı sıra, dünyadaki en iyi geleneksel fermente süt ürünlerinden biri olmasıyla ünlüdür. Lactobacillus acidophilus ve Bifidobacterium gibi probiyotiklerin Dunaliella salina ile fermente sütte canlılığının desteklenmesi önemli bir konudur. Besinler, $\mathrm{C}$ vitamini gibi vücudumuzda sentezlenemeyen veya belirli bir durumda belirli bir faktör gerektiren sentezlenebilen gıda bileşenleri olarak kabul edilir ve bazı amino asitler, vitaminler ve yă asitleri gibi eksik veya yetersizdir. yosun. Büyüyen araştırmalar, insan sağlığını ve beslenmesini mükemmelleştirmek ve zorlu ortamlarda bitki toleransını arttırmak için bitkilerde $\beta$-karotenin biyosentetik yollarını uygulamıştır. Dunaliella salina ilavesinin fermente sütteki probiyotik bakterilerin ilaveler ve saklama süresi yoluyla canlılığı üzerindeki etkisi önemli bir konudur. Bu nedenle "fonksiyonel gıda" olarak kabul edilir. Bu çalışmanın amacı, Dunaliella salina ekleyerek fermente sütün besin değerini arttırmak ve probiyotiklerin aktivitesini araştırmaktır. 


\section{Introduction}

Most of the nourishments which including probiotics can be suggested as useful bacteria with the prebiotic that are utilized and of the beneficial diet in Europe and Middle East (Vasiljevic and Shah, 2008). Probiotics are known healthy product for humans used as diet supplements. Many kinds of probiotics, like Lactobacillus, applied in milk products operations for a variety of health benefits (Mortazavian et al., 2006). So, there are certain types of Lactobacilli that are the most pivotal probiotic used as a part of probiotics products (Hoier, 1992). Probiotic bacteria, such as Lactobacillus and Bifidobacterium, source is Actinobacteria phylum and Firmicutes. Also, Lactobacilli are a part of the lactic acid bacteria group and are known as one a section of microorganisms that ferment several hexoses to lactic acid. Lactobacilli is a gram positive, phylogenetically various, with about 100 sort certified until now, anaerobic or microaerophilic, rod-shaped, and non-spore-forming microorganism (Makarova, et al., 2006). Yoghurt culture bacteria like Streptococcus thermophilus and Lactobacillus delbrueckii ssp. bulgaricus often use for manufacturing of yoghurt and product's bring medical usefulness by giving a defensive effect against DNA damage by the members brought on heterocyclic amines. Many tests showed that pre-carcinogenic enhance injuries in colon cells of rate low while the food was several by a suspension exists Lactobacillus bulgaricus (Zsivkovits et al., 2003). There are various clinical researches showed several benefits health advantages of probiotic like:

- Protection against cancer

- Enhancement of the suppressor cells

- Producing interferon

- Protecting against unfavorable complex.

- Manufacture of inhibitory complexes as acids, and $\mathrm{H} 2 \mathrm{O} 2$.

- Enhancing the immune system in body

- Promoting the digestion process

- Create of collections of vitamins

- Effect on lactose digestion

As well as, there are many studied on the survival of probiotic bacteria during preparing time and in the storage of fermented milk in the fridge (Beheshtipour et al. 2012). They suggested that integration of algae to the probiotic fermented milk products enhance the ability of probiotic and promote their functional properties.

\section{Lactic Acid Bacteria}

Lactic acid bacteria are chain of gram-positive bacteria including several of morphological, metabolic and physiological functions. Lactic acid bacteria have been used since old time due to their beneficial health effects on the host. There is much determination portraying probiotic health that probiotic bacteria should be tolerant to be spread its way through the gastrointestinal tract. Therefore there are many functions portraying probiotic health like:

- enhance effects on gastrointestinal contaminations

- controlling the antimicrobial and antiviral functions

- enhancing the lactose digestion
- controlling the whey cholesterol rate (Nakasawa and Hosono, 1992).

$\mathrm{LAB}$ is used as a starter culture, bio-protective specialize and consortium individuals in food products that promote food quality up to the time of usage. A group of probiotic kinds is accessible containing Lactobacillus acidophilus and Bifidobacterium that are shown for the improving of utilitarian diet products by health-promoting limits (Chávarri et al., 2010). Milk and fermented products are opulent in the usefulness of bacteria. Lactic acid bacteria are included between makings of products saving in mind the end time to start the fermentation ways. Streptococcus thermophilus and Lactobacillus delbrueckii ssp. bulgaricus are used as a starter culture in yoghurt also are using in account as a potential probiotic bacteria (Nadal et al., 2010). In the industry company of milk product, there are several requirements as oxygen ability to increase in milk products, heat tolerance and metabolize of prebiotics. So, the sensory functions necessary not to be impacted negatively (Nadal et al 2010). therefore the ability of probiotic bacteria as L. acidophilus, Bifidobacterium and yoghurt cultures bacteria could be exist and effected by add a pure cysteine into yoghurt operation which combined (Güler-Akin and Akin, 2007). A combination between probiotics and algae constitutes a symbiotic that could activate and enhance the existence of specific strains of probiotics in the intestinal tract. Also, the combination among probiotics and plant material has appeared to consult benefits for the body. Probiotics operations has been resulting to be a hopeful treatment to preserves and improving the intestinal environment. Many research studies have suggested that aquatic algae extracts of Spirulina platensis, Dunaliella salina and Chlorella extracts are possible sources for enhancing probiotic productions. Spirulina platensis extract considers as the great algal origin for the prebiotics that it had a huge stimulatory impact on growth of probiotic bacteria like $l$. acidophilus, L. bulgaricus L. lactis and B. longum. As long as, galactose and xylose described by HPLC in the algae extracts pretend oligosaccharides that assignment like prebiotic complex for promoting of probiotic (Gourbeyre et al., 2011)

\section{Dunaliella Salina}

Dunaliella salina is known as one kind of halophile green microalgae which found in sea salt place. It is common for its antioxidant behavior that is for its viability to prepare a big rate of carotenoids that utilized in beauty products and food supplements. Some of algae can survive such as Dunaliella salina does in such increase saline conditions like salt steaming fields. To live, the algae have huge rate of $\beta$-carotene to save against the intense light, it could increase rates of glycerol to improve protection on the osmotic pressure. The operation is a chance for commercial biological incubation of these materials (Oren, 2005). Morphemically Dunaliella is comparable to Chlamydomonas reinhardtii with the requisite without belong that Dunaliella lack both contractile vacuole and cell wall. Dunaliella contain two flagella has one length and same chloroplast include a basic pyrenoid. As well as the chloroplast could catch up with huge level of $\beta$-carotene, that can bring it show orange-red color. The $\beta$-carotene appears to protect the algae from a long-term UV radiation. Dunaliella salina is growth in its typical conditions. Dunaliella salina has many forms and symmetries depending on the conditions in its survival environments (Borowitzka and Michael, 2016). Also, the level of $\beta$-carotene is can active as an anti-oxidant and like a vitamin A. So, Dunaliella salina is a famous pro-vitamin A food 


\section{European Journal of Science and Technology}

supplements and beauty products (Mokady and Abramovici, 1989). As well as Dunaliella salina is as a source of vitamin B12 (Kumudha and Sarada, 2016).

The growing body of researches has suggested the biosynthetic steps of $\beta$-carotene in the plants for pioneer human health and nutrition and promoting plant tolerances under bad environments.

Carotenoids are one of the biggest parts of natural pigments with about 750 forms find in several algae including algae and greater plants (Fraser and Bramley, 2004). In the green texture of the plants, the carotenoids are existed on chloroplast and work as ancillary molecule of photosynthetic colors, against from photooxidative harm, and antioxidants under pressure (DemmigAdams and Adams, 2002). Through the non-green textures, carotenoids set uo chromoplast of plant with various pigments to catch pollinators and free seed (Howitt and Pogson, 2006). In carotenoids, $\beta$-carotene is famous as an origin of vitamin $\mathrm{A}$ and a impact operations for cardiovascular risks and cancer. Any way $\beta$-carotene could not be synthesized and it must be taken by bodies from taken food (Krinsky and Johnson, 2005). Depending on the founded of phytonutrients, it has reformist functions against several diseases and health problem as cancer, diabetes, hypertension, hypercholesterolemia, and anaemia diseases. The studies have appear that the extracellular products make by algae specially effect the growth of lactic acid bacteria like Lactobacillus acidophilus, Lactobacillus bulgaricus, Lactococcus lactis, Streptococcus thermophilus, and lactobacillus casei. So, this present paper focuses on the health efficiency of Dunaliella salina on probiotic microorganisms.

\section{Discussion and Conclusion}

$\mathrm{T}$ Several researchers inspected many properties of fermented milk products but particularly not well shown. The health benefits and supplement amounts of milk products are diversified, so it is advised to be using by people due to its advantages. The microbiological and chemical complex of fermented milk with algae could provide a probiotic impact due to the high amount of lactic acid bacteria. May future observations will appear more explanation about algae-milk products of their nutritional and therapeutic functions. That may use as functional food.

\section{Acknowledgment}

This paper has been boosted and supported by Gaziantep University, Turkey.

\section{References}

[1] Anantharajappa Kumudha 1, Ravi Sarada, Kumudha Anantharajappa, Sarada Ravi, Characterization of vitamin B12 in Dunaliella salina J Food Sci Technol . 2016 Jan;53(1):888-94.

[2] Beheshtipur H, Mortazavian AM, Haratian P, Khosravi K. Effect of chlorella and Arthrospira platensis addition on viability of probiotic bacteria in yoghurt and its biochemical properties. Euro Food Res Technol. 2012; 235: 1230- 1239.

[3] Borowitzka, M.A. (2016) Algal physiology and large-scale outdoor cultures of microalgae. In: Borowitzka, M.A., Beardall, J. and Raven, J., (eds.) The Physiology of Microalgae. Springer, pp. 601-652.
[4] Chávarri M., Marañón I., Ares R., Ibáñez F. C., Marzo F., Villarán M. C. 2010. Microencapsulation of a probiotic and prebiotic in alginate-chitosan capsules improves survival in simulated gastro-intestinal conditions. Int. J. Food Microbiol. 142 185-189. 10.1016/j.ijfoodmicro.2010.06.022

[5] Demmig-Adams, B., Adams, W.W., 2002. Antioxidants in photosynthesis and human nutrition. Science 298, 21492153.

[6] Fraser, P.D., Bramley, P.M., 2004. The biosynthesis and nutritional uses of carotenoids. Prog. Lipid Res. 43, 228265.

[7] Gourbeyre P, Denery S, Bodinier M. Probiotics, prebiotics, and synbiotics: impact on the gut immune system and allergic reactions. J Leukoc Biol. 2011;89(5):685-695.

[8] Güler-Akın, M. B., Akın, M. S. (2007). Effects of cysteine and different incubation temperatures on the microflora, chemical composition and sensory characteristics of bioyogurt made from goat's milk", Food Chemistry 100 (2), 788-793

[9] Hoier E. 1992. Use of probiotic starter cultures in dairy products. Food Australia 44:418-20.

[10]Howitt, C.A., Pogson, B.J., 2006. Carotenoid accumulation and function in seeds and non-green tissues. Plant Cell Environ. 29, 435-445.

[11]Krinsky, N.I., Johnson, E.J., 2005. Carotenoid actions and their relation to health and disease. Mol. Asp. Med. 26, 459516.

[12]Makarova، K. Slesarev، A.؛ Wolf‘ Y. Sorokin‘ A.؛ Mirkin B.؛ Koonin، E.؛ Pavlov، A.؛ Pavlova، N. (2006). "Comparative genomics of the lactic acid bacteria". Proc Natl Acad Sci U S A. 103 (42): 15611-6. PMC 1622870Freely accessible. PMID 17030793. doi:10.1073/pnas.0607117103.

[13]Mokady,S, Abramovici. A, Cog, U. Anthe Safety Evaluation Of Dunaliella Bardawil As A Potential Food Supplement. Fdchem. To :Ic. Vol. 27, No. 4. Pp. 221 226. 1989.

[14]Mortazavian, A. M. and Sohrabvandi, S. 2006. Probiotics and Food Probiotic Products; based on dairy probiotic products. tehran: Eta Publication.

[15]Nadal, E. S., E. Sayas-Barberá, J. Fernández-López, and J. A. Pérez-Alvarez. 2010. Food formulation to increase probiotic bacteria action or population. Bioactive Foods in Promoting Health: Probiotics and Prebiotics:335-351.

[16]Nakasawa Y, Hosono A. 1992. Functions of fermented milk. Challenges for the health sciences. London, England: Elsevier Applied Science.

[17]Oren, A. A hundred years of Dunaliella research: 19052005. Saline Systems 2005, 1:2.

[18]Vasiljevic, T. and Shah, N.P. (2008) Probiotics-From Metchnikoff to bioactives. International Dairy Journal 18 : 714-728.

[19]Zsivkovits, M., K. Fekadu, G. Sontag, U. Nabinger, W. W.Huber, M. Kundi, Asima Chakraborty, H. Foissy, and S. Knasmuller. 2003. Prevention of heterocyclic amine-induced DNA damage in colon and liver of rats by different Lactobacillus strains. Carcinogenesis 24(12):1913-1918.. 